\title{
Faktor - Faktor Penentu Pengaruh Kualitas Produk dan Harga terhadap Loyalitas Pelanggan Indosat IM3 OOREDOO
}

\author{
Slamet Heri Winarno \\ ASM BSI Jakarta \\ slamet.smh@bsi.ac.id \\ Bryan Givan \\ ASM BSI Jakarta \\ Yudhistira \\ AMIK BSI Tangerang
}

\begin{abstract}
Penggunaan jaringan internet dan telepon yang telah menyebar ke daerah terpencil membuat masyarakat menjadi lebih konsumtif dalam melakukan pembelian pulsa mereka sendiri. Dengan meningkatnya frekuensi penggunaan komunikasi dan data internet, Indonesia menjadi negara yang menguntungkan bagi operator seluler. Pada pertengahan 2015, Indosat memiliki 68,5 juta pelanggan, naik $24,7 \%$ dibanding periode yang sama tahun lalu 54,9 juta pengguna. Tujuan dari penelitian ini adalah untuk mengetahui faktorfaktor penentu loyalitas pelanggan khususnya kualitas dan harga produk. Metode penelitian yang digunakan adalah deskriptif kuantitatif, dengan menggunakan sampel 100 mahasiswa pengguna IM3 Ooredoo dari tiga perguruan tinggi di Jabodetabek. Hasil peneltian menunjukkan nilai $R$ square sebesar $62,9 \%$, yang mengindikasikan loyalitas pelanggan ditentuka oleh kualitas produk dan harga secara posistif dan signifikan dengan persamaan regresi $\mathrm{Y}=2,942+0,683 \mathrm{X} 1+0,346 \mathrm{X} 2$. Terjadi hubungan atau pengaruh dalam menciptakan loyalitas pelanggan baik secara simultan atau parsial.
\end{abstract}

Keyword Kualitas Produk, Harga, Loyalitas Pelanggan

\section{PENDAhUluAN}

Masyarakat modern kini telah memasuki zona komunikasi tingkat tinggi, dimana kebutuhan akan teknologi komunikasi sudah tergolong dalam kategori kebutuhan dasar manusia khususnya di Indonesia. Penggunaan internet yang telah menyebar ke pelosok daerah membuat masyarakat lebih konsumtif dalam pembelian data internet. Dengan frekuensi penggunaan alat komunikasi dan data internet yang begitu tinggi, Indonesia menjadi ladang bisnis yang menggiurkan bagi operator seluler. Telkomsel, Indosat dan Excelcomindo menjadi operator seluler yang memiliki pangsa pasar besar jika dibandingkan dengan pebisnis dari operator seluler yang ada.

Di pertengahan tahun 2015 Indosat telah memiliki pelanggan sebanyak 68,5 juta pengguna yang naik $24,7 \%$ dibandingkan periode sama tahun lalu sebesar 54,9 juta pengguna. Sekitar $40 \%$ hingga 50\% adalah pengguna data. Sepanjang semester I 2015 Indosat memiliki laba usaha sebesar Rp 1,04 triliun melesat dari posisi Rp 5 miliar di periode sama tahun lalu. Tingginya pengguna indosat sebanding dengan banyaknnya penghargaan yang diraihnya. Diantaranya di tahun 2015 lalu Indosat meraih penghargaan Brand of The Year di World Branding Awards 2015.

Indosat Ooredoo sadar bahwa pangsa pasar anak muda merupakan pasar yang sangat dinamis. Karena itu, Indosat pun harus adaptif terhadap perubahan yang sangat cepat berganti. Indosat kalah bersaing dengan Telkomsel dalam hal frekuensi sinyal. Sebelum berganti nama menjadi Indosat Ooredoo, keluhan pelanggan IM3 akan sinyal tidak sebanding dengan motto yang dimiliki Indosat "Sinyal Kuat Indosat" karena kenyataannya memang sinyal Indosat terutama IM3 terbilang kurang stabil dibanding para pesaingnya. 
Harga yang murah dan kualitas pelayanan yang baik menciptakan kepuasan sehingga berdampak pada kesetiaan atau loyalitas pelanggan dalam mengkonsumsi atau menggunakan jasa tersebut (Kurniasih, 2012). Kualitas produk berpengaruh positif namun tidak signifikan terhadap loyalitas (Pongoh, 2013). Penelitian lainnya juga menerangkan bahwa kualitas produk berpengaruh secara langsung terhadap loyalitas pelanggan (Syarifuddin dan Winarno, 2011). Berdasarkan latar belakang diatas perlu kiranya dikaji kembali pengaruh kualitas produk dan harga terhadap loyalitas pelanggan Indosat Ooredoo.

\section{TINJAUAN PUSTAKA}

\section{A. Kualitas Produk}

Kualitas produk merupakan proses evaluasi secara keseluruhan kepada pelanggan atas perbaikan kinerja suatu barang atau jasa (Hansen dan Mowen. 2005). Pendapat lain menyebutkan jika kualitas produk adalah kemampuan produk untuk menampilkan fungsinya, hal ini termasuk waktu kegunaan dari produk, keandalan, kemudahan dalam penggunaan dan perbaikan, dan nilai-nilai yang lainnya Kotler dan Armstrong, 2006)

Apabila perusahaan ingin mempertahankan keunggulan kompetitifnya dalam pasar, perusahaan harus mengerti aspek dimensi apa saja yang digunakan oleh konsumen untuk membedakan produk yang dijual perusahaan tersebut dengan produk pesaing (Ali, 2009). Menurut Kotler dan Keller (2006), dimensi kualitas produk yaitu: (1) performance (kinerja), berhubungan dengan karakteristik operasi dasar dari sebuah produk; (2) durability (daya tahan), yang berarti berapa lama atau umur produk yang bersangkutan bertahan sebelum produk tersebut harus diganti. Semakin besar frekuensi pemakaian konsumen terhadap produk maka semakin besar pula daya tahan produk; (3) conformance to specifications (kesesuaian dengan spesifikasi), yaitu sejauh mana karakteristik operasi dasar dari sebuah produk memenuhi spesifikasi tertentu dari konsumen atau tidak ditemukannya cacat pada produk.; (4) features (fitur), adalah karakteristik produk yang dirancang untuk menyempurnakan fungsi produk atau menambah ketertarikan konsumen terhadap produk; (5) reliabilty (reliabilitas), adalah probabilitas bahwa produk akan bekerja dengan memuaskan atau tidak dalam periode waktu tertentu. Semakin kecil kemungkinan terjadinya kerusakan maka produk tersebut dapat diandalkan; (6) aesthetics (estetika), berhubungan dengan bagaimana penampilan produk bisa dilihat dari tampak, rasa, bau, dan bentuk dari produk; (7) perceived quality (kesan kualitas), sering dibilang merupakan hasil dari penggunaan pengukuran yang dilakukan secara tidak langsung karena terdapat kemungkinan bahwa konsumen tidak mengerti atau kekurangan informasi atas produk yang bersangkutan

\section{B. Harga}

Harga menurut Dharmesta dan Irawan. (2005) adalah sejumlah uang (ditambah beberapa produk kalau mungkin) yang dibutuhkan untuk mendapatkan sejumlah kombinasi dari produk dan pelayanannya. Selain itu penulis lain menyebutkan bahwa harga adalah sejumlah uang yang ditagihkan atas suatu produk dan jasa atau jumlah dari nilai yang ditukarkan para pelanggan untuk memperoleh manfaat dari memiliki atau menggunakan suatu produk atau jasa (Kotler dan Armstrong, 2008).

Ali (2009) mengatakan jika harga merupakan segala bentuk biaya moneter yang dikorbankan oleh konsumen untuk memperoleh, memiliki, memanfaatkan sejumlah kombinasi dari barang beserta pelayanan dari suatu produk.

Indikator yang mencirikan harga menurut Kotler dan Armstrong. (2008) yaitu: (1) keterjangkauan harga; (2) kesesuaian harga dengan kualitas produk; (3) daya saing harga; (4) kesesuaian harga dengan manfaat produk; (5) harga mempengaruhi daya beli beli konsumen; (6) harga dapat mempengaruhi konsumen dalam mengambil keputusan.

\section{Loyalitas}

Dewasa ini perusahaan menghadapi persaingan yang sangat tajam dibanding sebelumnya. Sehingga perusahaan bergeser dari falsafah produk dan penjualan menjadi ke arah falsafah atas dasar 
pemasaran. Perusahaan yang terfokus pada pelanggan harus mahir di dalam membentuk dan menjaga hubungan dengan pelanggan, mereka harus ahli di dalam rekayasa pasar dan bukannya rekayasa produk.

Loyalitas pelanggan adalah suatu pembelian ulang yang dilakukan oleh seorang pelanggan karena komitmen pada suatu merek atau perusahaan (Kotler dan Armstrong. 2006.. Loyalitas juga memiliki 3 indikator menurut Kotler dan Keller (2006) diantaranya: (1) repeat purchase (kesetiaan terhadap pembelian produk); (2) retention (ketahanan terhadap pengaruh yang negatif mengenai perusahaan); (3) referalls (mereferensikan secara total esistensi perusahaan) . Loyalitas juga dapat disebabkan faktor nilai yang ada pada user yang tentunya dihasilkan dari penggunaan pelayanan yang diberikan [Syarifuddin dan Winarno, (2011). Setiap perusahaan akan berusaha memberikan layanan terbaik agar dapat menciptakan kepuasan konsumen serta mempertahankan loyalitas konsumen atau customer loyalty (Cheng, 2008).

\section{Kerangka Pemikiran}

Hal menarik tentunya dan patut untuk diteliti dan dikaji sejaumana para pelanggan dan pengguna Indosat Ooredoo tetap setia menggunakan produk ini ditengah persaingan yang cukup gencar antar sesama provider internet. Berdasarkan hal tersebut langkah awal yang dilakukan peneliti yaitu membuat model penelitian dalam bentuk kerangka pemikiran, seperti pada gambar 1 .

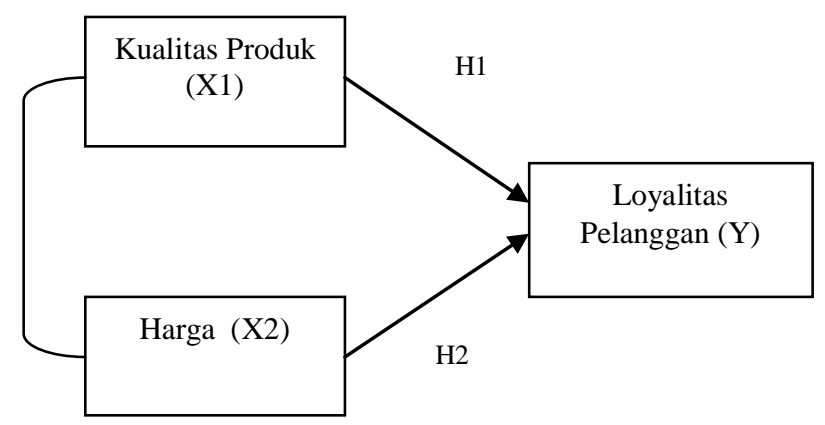

Gambar 1. Model Penelitian

Berdasarkan kerangka pemikiran tersebut selanjutnya dirumuskan hipotesis penelitian yaitu: (1) H1= diduga kualitas produk Indosat Ooredoo berpengaruh secara positif dan signifikan terhadap loyalitas pelanggan; (2) $\mathrm{H} 2=$ diduga harga paket Indosat Ooredoo berpengaruh secara positif dan signifikan terhadap loyalitas pelanggan

\section{METODE PENELITIAN}

Penelitian ini bersifat kuantitatif deskriptif dengan jenis penelitian survey, dan desain korelasional kausalitas, yang mencoba menganalisis pengaruh kualitas produk dan harga terhadap loyalitas pelanggan pengguna Indosat Ooredoo. Pengambilan sampel penelitian menggunakan sampling jenuh, yang mengindikasikan seluruh populasi merupakan responden sebanyak 100 orang, yang merupakan pengguna Indosat Ooredoo dari kalangan mahasiswa yang tersebar di tiga perguruan tinggi di Jabodetabek. Kategori sampel ini yang digunakan meliputi: jenis kelamin, usia, lama berlangganan, menggunakan pulsa per bulannya dan lama berlangganan.

Data yang digunakan adalan data primer dengan teknik pengumpulan data yang dilakukan yaitu: (1) kuesioner; (2) wawancara (Interview), dan (3) observasi, menggunakan skala Likert Teknik analisa data menggunakan analisa sattistik Ordinary Least Square yaitu suatu metode ekonometrik dimana terdapat variable independen yang merupakan variable penjelas dan variable dependen yaitu variable yang dijelaskan dalam suatu persamaan linier berganda guna mendapatkan hasil berupa pengaruh diantara dua variabel tersebut (Sugiyono. 2010). Rangkaian uji yang dilakukan meliputi: uji validitas dan reliabilitas, uji asumsi klasik, analisis korelasi berganda, koefisien determinasi, regresi linier berganda, uji 
F dan uji t (Mahadianto Yudi dan Setiawan., 2013) Hubungan diantara variabel dalam penelitian ini dinyatakan sebagai:

$$
\mathrm{Y}=a+\beta 1 \mathrm{X} 1+\mathrm{X} 2+e
$$

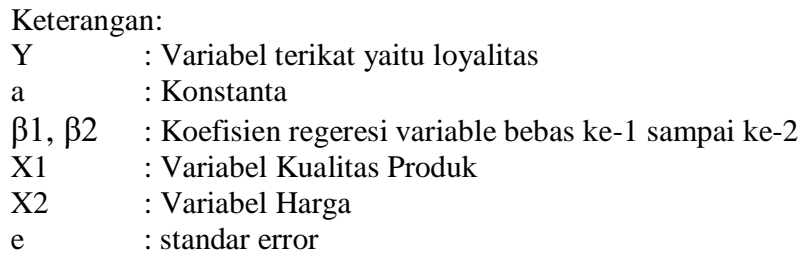

\section{HASIL DAN PEMBAHASAN}

Indosat Ooredoo adalah salah satu perusahaan penyedia jasa telekomunikasi dan jaringan telekomunikasi di Indonesia. Perusahaan ini menawarkan saluran komunikasi untuk pengguna telepon genggam dengan pilihan pra bayar maupun pascabayar dengan merek jual Matrix Ooredoo, Mentari Ooredoo dan IM3 Ooredo, jasa lainnya yang disediakan adalah saluran komunikasi via suara untuk telepon tetap (fixed) termasuk sambungan langsung internasional IDD (International Direct Dialing). Indosat Ooredoo juga menyediakan layanan multimedia, internet dan komunikasi data (MIDI= Multimedia, Internet \& Data Communication Services). Pada tahun 2011 Indosat Ooredoo menguasai $21 \%$ pangsa pasar. Pada tahun 2013, Indosat Ooredoo memiliki 58,5 juta pelanggan untuk telefon genggam. Pada tahun 2015 Indosat Ooredoo mengalami kenaikan jumlah pelanggan sebesar 68,5 juta pelanggan dengan presentasi naik 24,7\%, dibandingkan periode tahun 2014 sebesar 54,9 juta pengguna. Indosat Ooredoo merupakan layanan seluler prabayar yang dengan kemampuan isi ulang yang dimiliki oleh operator Indosat dan didirikan pada tahun 2001. Dengan produknya IM3 Ooredoo, maka Indosat menjadi operator pertama yang dengan inovasinya tersebut siap mendukung GPRS, MMS, video treaming hingga java games di seluruh Indonesia. IM3 Ooredoo tersedia dengan layanan pita lebar, layanan paket data dengan kecepatan tinggi hingga 2 mbps dan paket-paket lainnya. Pada tahun 2015 , IM3 Ooredoo (pada saat itu bernama Indosat IM3) meluncurkan kartu perdana yang dinamakan IM3 Pinternet dan mendukung salah satu perusahaan asal Facebook, yaitu Internet.org.

Hasil penelitian menunjukkan berdasarkan karakteristik sampel pengguna Indosat IM3 Ooredoo didominasi oleh gender wanita sebesar $74 \%$, dan pria $26 \%$. Hal ini memperlihatkan bahwa kecenderungan produk IM3 Ooredoo ini disukai oleh kaum wanita. Penelitian ini juga menghasilkan data bahwa sebesar 51\% responden telah menjadi pelanggan Indosat IM3 Ooredoo selama 3-5 tahun. Kemudian 28\% responden telah menjadi pelanggan Indosat IM3 Ooredoo selama 6-10 tahun dan sisanya $21 \%$ responden telah menjadi pelanggan Indosat IM3 Ooredoo selama 1-2 tahun. dengan penggunaan pulsa dalam setiap bulannya 68\% responden menggunakan pulsa sebesar Rp51.000-Rp100.000 dalam kurun waktu satu bulan sedangkan sisanya sebanyak $32 \%$ responden menggunakan pulsa lebih dari Rp100.000 perbulan

Hasil perhitungan statistik terhadap reliabilitas variabel-variabel penelitian menunjukkan angka diatas 0,70 . Ini menunjukkan kelayakan dari model dan variabel penelitian yang digunakan. Hasil lainnya secara validitas diketahui nilai dari $\mathrm{r}$ tabel menggunakan 100 sampel dengan taraf keyakinan 5\% diperoleh hasil 0,196, dan selanjutnya dibandingkan dengan nilai $r$ hitung, dan menghasilkan nilai valid pad seluruh responden. Di sisi lain, Penelitian ini juga menghasilkan nilai tolerance sebesar 0,212>0,1 dan nilai VIF 4,726 < 10 dari variabel kualitas produk dan harga, berarti tidak terjadi Multikolineraritas dari masing-masing variabel independen.Hasil uji normalitas digambarkan pada grafik p-plot (gambar 1) yang menunjukkan sebaran dari data yang konsisten sehingga dapat dikatakan data bersifat normal. 


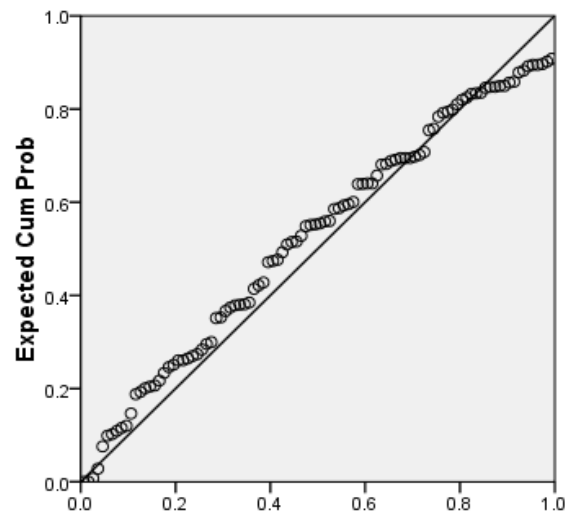

Sumber : Hasil olah data Gambar 1, Grafik Normal P=P

Hasil penelitian juga menghasilkan nilai $\mathrm{R}$ square sebesar 0,692, yang mengindikasikan bahwa loyalita pengguna IM3 Ooredoo dipengaruhi oleh kualitas produk dan harga sebesar 69,2\% sedangkan sisanya dipengaruhi oleh faktor-faktor lain di luar kedua varibel tersebut. Dihasilkan pula nilai-nilai statistik yang digunakan dalam membentuk persamaan regresi seperti pada tabel 1.

Tabel 1.Hasil Output Regresi

\begin{tabular}{|c|c|c|c|}
\hline & \multirow[b]{2}{*}{ Model } & \multicolumn{2}{|c|}{$\begin{array}{c}\text { Unstandardized } \\
\text { Coefficients }\end{array}$} \\
\hline & & $\mathrm{B}$ & Std. Error \\
\hline \multirow[t]{3}{*}{1} & (Constant) & 2.942 & 3.051 \\
\hline & Kualitas_Produk & .683 & .143 \\
\hline & Harga & .346 & .157 \\
\hline
\end{tabular}

Berdasarkan data diatas maka persamaan regresi untuk penelitian ini yaitu : $\mathrm{Y}=2,942+0,683 \mathrm{X} 1$ $+0,346 \mathrm{X} 2+\mathrm{e}$. Hal ini menunjukkan setiap peningkatan satu unit kualitas produk maka loyalitas akan meningkatkan sebesar 0,683 dan setiap peningkatan satu unit harga maka loyalitas akan meningkat sebesar 0,346.

Berikutnya yaitu melakukan uji hipotesis, hasil uji menunjukkan nilai $\mathrm{F}$ hitung sebesar 108,783 lebih besar dari nilai $\mathrm{F}$ tabel sebesar 3,09 atau nilai signifikasi lebih kecil dari nilai 0,05 sehingga dapat dikatakan bahwa secara simultan kualitas produk dan harga berpengaruh positif dan signifikan terhadap loyalitas pelanggan.

Uji hipotesis juga dapat dilakukan secara parsial dengan mengguna uji t, hasil uji menunjukkan: (1) kualitas produk (X1) dengan nilai t hitung sebesar 4,760 lebih besar dari t tabel sebesar 1,984, dan taraf signifikasi lebih kecil dari 0,05. Sehingga menjawab hipotesis bahwa variabel kualitas produk memberikan pengaruh positif dan signifikan terhadap loyalitas pelanggan; (2) harga (X2) dengan nilai t hitung sebesar 2,196 lebih besar dari t tabel sebesar 1,984, dan taraf signifikasi lebih kecil dari 0,05 Sehingga menjawab hipotesis bahwa variabel harga memberikan pengaruh positif dan signifikan terhadap loyalitas pelanggan.

Persaingan antara operator penyedia jasa jaringan internet dewasa ini makin dirasakan sangat ketat, ditandai dengan makin banyaknya varian produk yang beragam beserta keunggulannya. Setiap pelanggan dihadapkan pada berbagai macam pilihan yang memaksanya harus memilih produk yang mampu menciptakan kepuasan tersendiri dan pada akhirnya akan berdampak pada loyalitas. Namun, tidak 
hanya dari ragam varian saja pelanggan akan loyal terhadap suatu produk, di sisi lain perlu juga diperhatikan dari sisi kualitas dari produk itu sendiri, semakin baik kualitas dari produk semakin suka pelanggan akan produk tersebut dan akan menggunakannnya untuk waktu yang lama. Hal ini terbukti dengan hasil dari penelitian ini bahwa produk IM3 Ooredoo ini telah diterima dan disukai oleh pelanggan khususnya para mahasiswa perguruan tinggi yang ada di Jabodetabek. Hal ini sejalan dengan penelitian yang menyatakan bahwa kualitas produk berpengaruh pada loyalitas pelanggan (Adi, 2013) (Pongoh, 2013).

Indosat Ooredoo dengan produknya IM3 Ooredoo telah mampu menciptakan produk dengan kualitas yang sangat baik, baik dari sisi kualitas jaringan, paket kuota internet, serta harga yang sangat terjangkau bagi pelanggan. Persepsi terhadap harga dari para pengguna IM3 Ooredoo yang mereka rasakan menunjukkan trend yang positif, dimana mereka yakin bahwa apa yang telah mereka keluarkan untuk konsumsi mereka telah mampu memberikan loyalitas

Harga akan menjadi faktor yang sangat penting dalam menciptakan kepuasan pelanggan, karena apabila seorang pelanggan mengidentifikasi nilai dari suatu barang yang diterima, hal utama yang akan dilakukan adalah memikirkan masalah harganya (Saladin, 2006). Penelitian lain juga mengatakan bahwa harga produk berpengaruh positif terhadap loyalitas pelanggan (Syarifuddin dan Winarno, 2011).

Keberhasilan IM3 Ooredoo ini dalam membangun loyalitas pelanggan tentunya tidak lepas dari dukungan pihak manajemen melalui perusahaan Indosat Ooredoo yang terus menerus melakukan berbagai inovasi baru terhadap produknya guna tercapainya tujuan dari perusahaan yaitu building customer loyalty di berbagai kalangan.

\section{KESIMPULAN DAN SARAN}

Berdasarkan pembahasan yang telah diuraikan maka dapat disimpulkan bahwa pelanggan IM3 Ooredoo dari kalangan mahasiswa lebih mengutamakan tingginya kualitas produk dari produk yang mereka gunakan, sehingga mereka dengan senang hati tidak akan berpindah ke produk lain. demikian juga dengan faktor harga yang menjadi komponen penting dalam menciptakan loyalitas di kalangan mahasiswa dalam menggunakan IM3 Ooredoo. Ini juga dibuktikan dengan hasil perhitungan statistik bahaw 69,2\% loyalitas yang ditimbulkan pada penggunaan IM3 Ooredoo di kalangan mahasiswa dipengaruhi oleh kualitas produk dan harga.

Dengan naiknya jumlah pelanggan Indosat IM3 Ooredoo disetiap tahunnya, diharapkan Indosat IM3 Ooredoo tetap menjaga kestabilan kualitas produk dan harga yang dimilikinya, guna menjaga loyalitas pelanggan. Diharapkan Indosat IM3 Ooredoo bisa menjaga kestabilan sinyal terutama saat perubahan musim dan di hari-hari raya disepanjang tahunnya.

\section{REFERENSI}

Adi, Rifqi Purwo. 2013. Pengaruh Kualitas Produk dan Kewajaran Harga Terhadap Loyalitas dengan Kepuasan Konsumen Sebagai Variabel Intervening. Management Analysis Journal vol.2 no.1 hal 110-115. ISSN 2252-6552.

Ali, Hasan. 2009.Marketing Edisi Baru. Yogyakarta: Media Pressindo.

Cheng, Lai and Yeung, (2008), "The Driving Forces of Customer Loyalty: A Study of Internet Service Providers in Hong Kong." International Journal of E-Business Research, 4(4), 26-42

Dharmesta, B. S dan Irawan. 2005. Manajemen Pemasaran Modern. Edisi 2.Yogyakarta: Liberty.

https://indosatooredoo.com/id/about-indosat

Hansen dan Mowen. 2005. Management Accounting. Buku 2. Edisi 7. Jakarta: Salemba Empat.

Kotler, Philip dan Gary Armstrong. 2006. Prinsip-prinsip Pemasaran. Edisi 12. Erlangga. Jakarta. 
Kotler. Philip dan Gary Armstrong. 2008. Prinsip-prinsip Pemasaran. Jilid 1. Jakarta: Erlangga.

Kotler, Philip dan Kevin L. Keller, 2006. Marketing Management, Pearson Education Inc.

Kurniasih, Indah Dwi. 2012. Pengaruh Harga dan Kualitas Pelayanan terhadap Loyalitas Pelanggan melalui Variabel Kepuasan (Studi pada Bengkel AHASS 0002-Astra Motor Siliwangi Semarang). Jurnal Administrasi Bisnis Vol. I No. 1 hal. 37-45.

Perangin Angin, Jasanta, (2009), "Studi Peningkatan Loyalitas Pelanggan Ritel (Studi Kasus Toko Amelina)". Tesis. Megister Manajemen. Universitas Diponegoro Semarang

Mahadianto, Moh. Yudi dan Adi Setiawan. 2013. Analisis Parametrik Dependensi dengan program SPSS. Jakarta. PT Rajagrafindo Persada.

Pongoh, Melysa Elisabeth. 2013.Kualitas Pelayanan, Kualitas Produk dan Harga Pengaruhnya terhadap Loyalitas Pelanggan Kartu AS Telkomsel di Kota Manado. Jurnal EMBA. Vol.1 No.4 Hal 86-94. ISSN 2303-1174.

Saladin, H.Djaslim, (2006), Manajemen Pemasaran. Bandung: Linda Karya

Sugiyono. 2010. Metode Penelitian Bisnis (Pendekatan Kuantitatif, Kualitatif, dan R\&D). Bandung: Alfabeta.

1. Syarifuddin, Didin dan Slamet Heri Winarno, (2011), "Building Customer Value To Increase Number Of Tourits (Implementing Five Basic Concepts In Increasing Customer Value By Kotler) . Proceeding. International Seminar on Scientific Issues and Trends (ISSIT). p C1-C7

2. Wijayanti, Ari, (2008), "Strategi Meningkatkan Loyalitas Melalui Kepuasan Pelanggan (Studi Kasus: Produk Kartu Seluler Prabayar Mentari Indosat Wilayah Semarang)". Tesis. Megister Manajemen. Universitas Diponegoro Semarang. 